\title{
Consensus building in social marketing campaigns through the Delphi method
}

\begin{abstract}
This paper investigates the application of the Delphi method as a tool for building stakeholder consensus on the impact and prioritization of campaign initiatives as applied in a campaign to promote water efficiency behaviour. To date, use of the Delphi method has been underutilized and not yet applied to evaluating and prioritizing social marketing initiatives. Ten potential initiatives were developed during previous research, aiming to promote water efficiency in tourism accommodation. A Delphi panel of experts $(n=21)$ in tourism, water and social marketing evaluated, prioritized and rated the importance of factors used for prioritizing each initiative. Three initiatives received the greatest level of prioritization and were considered to have the highest effectiveness to reach project goals. In the context of this research, a Delphi consultation was a viable method toward this application. Best practices and limitations unique to the social marketing process are offered to aid future social marketing efforts in applying the Delphi method.
\end{abstract}

Keywords- Delphi method, consensus, water behaviour, tourism accommodation

\section{Introduction}

Researchers and practitioners have focused on the need for directing social marketing campaigns at different audiences which represent varying levels of influence over the desired behaviour change (e.g. Hastings, 2007; Lee and Kotler, 2011; Hall, 2016). The metaphor of a river has been used to describe this differentiation where initiatives and stakeholders have been considered upstream, midstream or downstream (Hastings, 2007). For Andreasen (2012), downstream targeting focuses on individuals with a 'problem behaviour.' Lee and Kotler (2011), identify midstream interventions as targeting those individuals close to and directly affecting the individuals performing the 'problem behaviour.' They offer the example of teaching parents or midwives the most effective ways to interact with teens about the importance of HIV/AIDS testing. Russell-Bennett et al. (2013) add that midstream also includes stakeholders within the community in which individuals live/interact. Alternatively, 
upstream marketing aims to engage the peripheral stakeholders affecting those behaviours, such as government, media and corporate partners (Niblett, 2005).

Hall (2014) identifies, effective social marketing campaigns are often directed at varying audiences (i.e. downstream and upstream) and commonly produce multiple viable initiatives to change behaviour. When multiple initiatives are produced, Lee and Kotler (2015) explain that prioritizing viable options for intervening can increase the likelihood of a successful campaign. By focusing on fewer interventions it may be possible to better direct resources towards their success. This is particularly important when campaign resources are scarce. To date, the process of evaluating and prioritizing numerous initiatives, directed towards varying audiences, has received little attention in the social marketing literature. Potential outcomes, created during conventional marketing campaigns, could be evaluated and prioritized unilaterally by a hired third party, through group consensus between key individuals within the business (Tafreshi et al., 2015), co-created between consumers and producers (Shaw et al., 2013) or some combination of these processes. These methods each possess practical and theoretical limitations. For example, it is not always possible or ethical to bring multiple stakeholders together in the same place in certain context as would be needed for co-creation (Domegan, Collins, Stead, McHugh, Hughes, 2013). This may be increasingly true in a field such as social marketing which can work to change behaviour in difficult topic areas (e.g. sexual assault, drug use, sensitive medical issues and environmental degradation). Within these difficult spaces, Fox and Kotler (1980) and Bloom and Novelli (1981) identify audiences may be more inclined to report false behaviours or not participate. Other limitations may involve high costs, a lack of input from key stakeholders or large geographical distances between important decision makers. One potential method for overcoming such limitations may be the Delphi method. 


\section{The Delphi Method}

The Delphi method has been used extensively in the conventional marketing literature to evaluate and advance theory (see Best, 1974; Richard and Curran, 2002; Kerr and Patti, 2015) though with limited application in the field of social marketing (see Ling, et al., 1992; Griffiths, et al., 2009; Johnson, et al., 2009; Aschemann-Witzel, et al., 2012). A Delphi consultation is a series of repetitive surveying events which usually aim to discover consensus on issues with a selected panel of experts (Linstone and Turoff, 1975).

Importantly, panel members are confidential and, more recently, commonly conducted online (Kerr and Patti, 2015). First applied in the cold war to predict enemy attacks (Diamond et al. 2014), the Delphi method was later developed in 1953 by Olaf Helmer and Norman Dalkey for the U.S. RAND Corporation as a tool to include the 'voice' of the practitioner and academic (Buckley, 1995). Stitt-Gohdes and Crews (2004) argue that the Delphi technique is usually applied because one or more of the following issues exist: The questions do not lend themselves to other qualitative or quantitative methods; judgment, toward consensus, by a given group is desired; it is not possible to have the sample in the same place for face-to-face communication due to time and/or money; more individuals are needed than are possible to have in face-to-face communication; or, the issue is so contentious that confidentiality and seclusion are needed.

While the method has been applied variably within the literature (Rowe and Wright, 1999), a common procedure has evolved. As described in several works (e.g. Okoli and Pawlowski, 2004, Garrod and Fyall, 2005; Hsu and Sanford, 2007) the first round asks a panel to establish a base line of which issues to investigate and evaluations of some preexisting questions. During subsequent rounds, results from the previous round are presented to panel members and the panel is asked to re-answer questions. The process is repeated for a specified number of rounds or until consensus is reached. 
Due to the many varying uses of the Delphi technique; poor explanation of the process when reporting results and concerns over small sample sizes, this technique has been criticised in the literature (e.g. Stewart, 1987; Bowers, 1997; Rowe and Wright, 1999; Garrod and Fyall, 2005). Highlighting these limitations, through a meta-analysis of 100 studies using the Delphi method, Diamond et al. (2014) found a lack of continuity in reporting between studies. Specifically they highlighted a high absence of: reporting on the purpose of the Delphi (i.e. is the goal to find consensus or just quantify agreement?); the criteria for how participants were selected; how consensus was defined; threshold values used for determining consensus if applicable; if items were dropped between rounds of surveying; and, stopping rules for discontinuing the consultation.

In this research, unique to past efforts, the Delphi technique was applied to build consensus on evaluating and prioritizing initiatives aiming to promote water efficient behaviour in tourism accommodation. Building consensus is important to social marketing efforts as it may empower stakeholders to steward campaigns through ensuring a greater amount of opinions have been validated. The term 'building consensus' is specifically applied here as the Delphi Method, through multiple rounds, relies on reflection on other panel members' responses, slowly moving the group towards consensus on an issue. Previously in this research project, ten potential initiatives were developed through the social marketing process. This paper aims to investigate the application of the Delphi method as a tool for building consensus on evaluating and prioritizing initiatives, offering an alternative process toward this end. In addition, recommendations and limitations for use of this method, specific to the field of social marketing, are provided. Finally, findings from this research are discussed with respect to their implication for several contemporary theoretical issues within the field of social marketing. 


\section{Methods}

The research was conducted in collaboration with a primary water distribution and sewage collection company, South West Water, aiming to promote water efficiency in small and medium sized tourism accommodations businesses in South West England. This location and collaborating company were chosen as they had previous experience with a social marketing campaign, called 'Love your Loo,' aiming to stop individuals from flushing unwanted materials down the toilet (South West Water, 2016), providing a study area and partner with crucial previous knowledge of the social marketing process.

Prior to the current research, through an intensive four stage research process involving focus groups and semi-structured interviews with tourism accommodation managers and questionnaires distributed among potential guests, ten possible initiatives aiming to promote water efficiency were realized. Figure 1 presents the overarching research process where the Delphi method was used as the final stage. This paper exclusively examines the findings from this final stage. Some result from previous stages have been published in Coles, Warren, Borden and Dinan (2016) and Borden, Coles and Shaw (2017), though in one instance, data was reworked to discover potential initiatives specifically aimed at promoting water efficiency. Table 1 presents a brief description of the ten initiatives emerging from previous stages to orient the reader.

Figure 1 Flow of methods to develop initiatives evaluated and prioritized by the Delphi consultation.

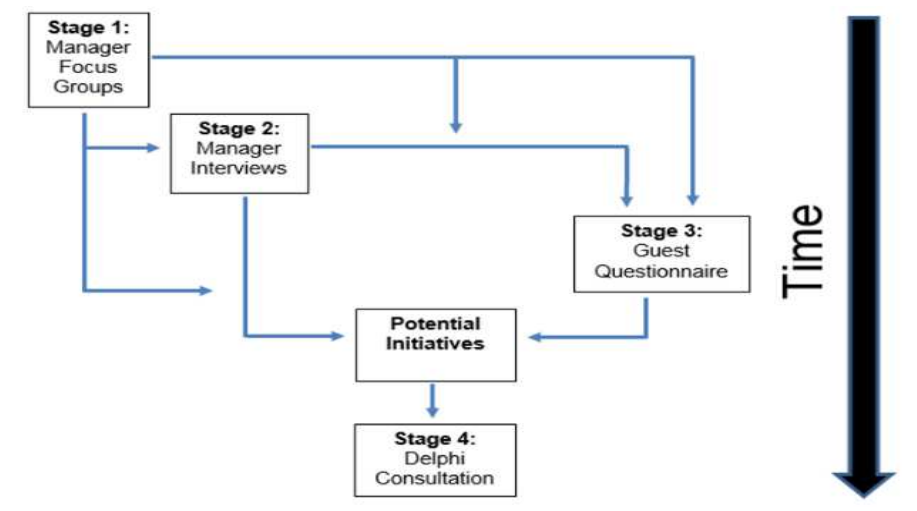

Source: authors 
Table 1 Brief description of initiatives created during previous stages of the social marketing campaign aiming to promote water efficient behaviour in tourism accommodation.

\begin{tabular}{|c|c|}
\hline Initiative & Brief Description \\
\hline $\begin{array}{l}\text { Remove } \\
\text { Competing } \\
\text { Behaviours }\end{array}$ & $\begin{array}{l}\text { Eliminating certain aspects of the guest experience could better enable } \\
\text { guests to make an easier decision to use water efficiently. For example, } \\
\text { removing baths showed little impact on the guest experience and cold } \\
\text { save a great amount of water. Another example is providing on-demand } \\
\text { water heaters to reduce time guests need to run water, wasting it, before it } \\
\text { becomes hot. }\end{array}$ \\
\hline $\begin{array}{l}\text { Feedback } \\
\text { Cards }^{d}\end{array}$ & $\begin{array}{l}\text { Providing cards located in guest rooms asking for additional ideas for } \\
\text { saving water (and other environmental efforts) in the accommodation. } \\
\text { This initiative would engage guests in the creation of solutions and may } \\
\text { encourage them to use resources more efficiently if they are part of the } \\
\text { 'solution.' }\end{array}$ \\
\hline $\begin{array}{l}\text { Initial } \\
\text { Welcome }^{\mathrm{d}}\end{array}$ & $\begin{array}{l}\text { Engaging guests on their initial walk through of the premises with a brief } \\
\text { (5-15 minutes) highlight of environmental efforts in addition to the original } \\
\text { pertinent information to show guests the business is making an effort and } \\
\text { hope guests follow suit. For example, while showing off the bathroom, the } \\
\text { popularity of the towel reuse program and the water saving shower heads } \\
\text { would be emphasised. }\end{array}$ \\
\hline $\begin{array}{l}\text { Child Focused } \\
\text { Messages }^{d}\end{array}$ & $\begin{array}{l}\text { Displaying signs asking guests to use only the water they need directed } \\
\text { towards children with the hope they will in turn influence their parents. }\end{array}$ \\
\hline Incentives $^{\mathrm{d}}$ & $\begin{array}{l}\text { Providing tangible (vouchers, gifts or money) items if guests participate } \\
\text { in towel reuse schemes or other efforts to reduce water usage. }\end{array}$ \\
\hline $\begin{array}{l}\text { Meaningful } \\
\text { Units of } \\
\text { Measurement }\end{array}$ & $\begin{array}{l}\text { Communicating water usage to tourism accommodation managers in } \\
\text { alternative units such as cost, cost relative to other similar businesses, } \\
\text { cost relative to past bills or facial expressions dictating their usage } \\
\text { compared to the norm. }\end{array}$ \\
\hline $\begin{array}{l}\text { Green } \\
\text { Ambassadors m }\end{array}$ & $\begin{array}{l}\text { Organizing events where owners/managers display and discuss their best } \\
\text { effort to save water at their establishments to their peers. Also, provide a } \\
\text { platform for those individuals innovating in this area to be contacts for } \\
\text { others. }\end{array}$ \\
\hline $\begin{array}{l}\text { Low Interest } \\
\text { Loans } \mathrm{m}\end{array}$ & $\begin{array}{l}\text { Increasing access to and/or create new avenues for businesses to secure } \\
\text { low interest loans with quick payback periods. }\end{array}$ \\
\hline $\begin{array}{l}\text { Green } \\
\text { Business } \\
\text { Scheme }\end{array}$ & $\begin{array}{l}\text { Enhancing existing or creating new certification schemes for 'green' } \\
\text { tourism efforts with added value. This could include increased marketing } \\
\text { assistance, access to 'buyers clubs' to reduce purchasing costs and } \\
\text { increased access to current research and best practices. }\end{array}$ \\
\hline $\begin{array}{l}\text { Increased } \\
\text { Academic } \\
\text { Collaboration }{ }^{m}\end{array}$ & $\begin{array}{l}\text { Encouraging greater efforts to engage owners/managers of tourism } \\
\text { accommodation in action research and provide them findings in an easy } \\
\text { to read format. }\end{array}$ \\
\hline
\end{tabular}

${ }^{\mathrm{d}}$ Indicates initiative aimed to change downstream (guest) behaviour

mIndicates initiative aimed to change midstream (business) behaviour

Source: authors

Summarizing previous efforts, managers were asked to create initiatives for reducing

water use and guests were asked how each idea would affect their experience in tourism 
accommodation. Ultimately, five initiatives targeting downstream (guest) behaviour and five targeting midstream (business) behaviour emerged. It was justified to involve multiple audiences here as the behaviour of managers directly affects the behaviour of guests and vice versa. For example, promoting towel reuse programmes through providing incentives for participants, fundamentally changes the managers operations (change in behaviour) yet is targeted at the guests' behaviour (participation in a program). Additionally, two different audiences were chosen for this project to enable us to collect information on downstream (guests) and midstream (managers) preferences in relation to the proposed ten initiatives.

Similar work has been conducted by Johnson, et al., (2009) who applied the Delphi method to solicit theory which panel members felt were most important in developing social marketing initiatives for primary prevention of skin cancer among adolescents and young adults. These theories were then used to create social marketing initiatives and obtain agreement on their impact. In Jones et al. (2014) these initiatives were expanded upon, using a third party to co-create and test potential initiatives with groups of young people. In contrast, this research is unique in that it started by creating initiatives with downstream (guests) and midstream (businesses) stakeholders, later using the Delphi method to evaluate and prioritize them. Both efforts followed the recommendations of McKenzie-Mohr and Smith (1999), incorporating those stakeholders most affected by initiatives, increasing the possibility of success. However, the current research used the Delphi method in a fundamentally different role and as such, findings and subsequent recommendations are explicitly stated for this purpose.

Here the Delphi consultation, conducted through an online survey, aimed to evaluate the effectiveness of each initiative created through results from stages 1-3; to rank potential initiatives in order of priority for implementation; and, to measure the factors used by panellist to prioritize them. Measurement of the effectiveness of each initiative and the 
factors used by panellist to prioritize initiatives were scored on five point Likert scales. Ranking initiatives for priority was measured on a weighted rank score corresponding to each individual panellists' response. When evaluating the ten initiatives, panel members were presented with results from previous stages of the research and provided with a visual example of each initiate to ensure they had all available information concerning the initiatives when completing the survey. After round one, both quantitative and qualitative responses from participants were provided to the panel to compare their response to those of their peer's as recommended by Diamond et al. (2014). No items were dropped between rounds, meaning all questions were again tested in round two. It was pre-determined that the consultation would stop once consensus was reached on most issues. Two rounds of surveying were conducted, at which time consensus, determined through pre-determined qualitative and quantitative metrics, specific to the question being asked and explained in detail in the results section of this paper, was reached and the Delphi was discontinued.

There has been some debate as to the merits of a homogeneous sample versus a heterogeneous sample with Powe (2003) concluding heterogeneous samples provide richer data set. Due to this recommendation and the multidisciplinary nature of social marketing, it was justified to use a heterogeneous panel here. Following the suggestions of Gibbs, Graves and Bernas (2001), experts were selected on the predetermined criteria that they had: published papers on the subject in the past five years in academic journals; taught University level courses on the subject; or, the subject was a primary function of their professional career for over five years. Experts were recommended by the South West Water Company, local sustainable tourism consultants and through a literature review of academic research in water, tourism management and social marketing. As the researchers in this study have previously worked in these disciplines, and in this geographic location, some individuals 
(under 20\%) participating in the consultation were previous colleagues. This limitation is discussed further in the discussion section of this paper.

In total, email invitations were sent to 24 individuals requesting their voluntary participation in the consultation. An acceptance rate of $87.5 \%$ was achieved and Table 2 reports brief descriptions of each of the participants $(n=21)$. Roughly, panel members can be categorized as: academic lecturers specializing in tourism or water issues (5); consultants in water or sustainable tourism (2); social marketing professionals or academic lecturers (3); governmental water or tourism professionals (2); directors of water efficiency or sustainable tourism non-profit organizations (2); tourism accommodation managers (4); and, professionals with experience in social marketing, tourism and water efficiency employed by the local water company, South West Water (3). Delphi consultations have been conducted with as few as 4 and as many as 904 participants (Smith, 1995). It was anticipated that participants would drop out of the exercise over time and thus a final sample of 15-20 individuals was desired, as recommended by Young et al. (1989). Two individuals did not complete round two and thus the sample size for the second round was 19 , representing over a $90 \%$ completion rate. Participants spent an average of over 45 minutes on each round to thoroughly investigate all 10 initiatives. These efforts yielded over 100 qualitative and quantitative data points for analysis.

Diamond et al. (2014) found no agreement within the literature on the procedure for determining consensus in a Delphi study. Rather they identify several different approaches for determining consensus within the literature including level of agreement, interquartile range, decrease in variance, stability between rounds and central tendency within a range. These variations may exist due to the varying type, length and nature of questions being asked in different Delphi studies. 
Table 2 Brief description of each Delphi member and round(s) of participation.

\begin{tabular}{|c|c|c|c|}
\hline Participants' Names & Brief Title & $\begin{array}{l}\text { Round } \\
\text { One }\end{array}$ & $\begin{array}{l}\text { Round } \\
\text { Two }\end{array}$ \\
\hline Participant A & Author and Consultant in Social Marketing & $\mathrm{X}$ & $\mathrm{X}$ \\
\hline Participant B & $\begin{array}{l}\text { Consultant of Applying Social Marketing in } \\
\text { the South West England Tourism Industry }\end{array}$ & $\mathrm{X}$ & $\mathrm{X}$ \\
\hline Participant $\mathrm{C}$ & Tourism Accommodation Manager & $\mathrm{X}$ & $\mathrm{X}$ \\
\hline Participant D & Tourism Accommodation Manager & $\mathrm{X}$ & $\mathrm{X}$ \\
\hline Participant E & $\begin{array}{l}\text { Special Projects Manager, Social Marketing } \\
\text { and Water Liaison }\end{array}$ & $\mathrm{X}$ & $\mathrm{X}$ \\
\hline Participant $\mathrm{F}$ & $\begin{array}{l}\text { University Lecturer of Marketing; Research } \\
\text { Including Investigations of Water Issues with } \\
\text { Water Companies }\end{array}$ & $\mathrm{X}$ & $\mathrm{X}$ \\
\hline Participant $\mathrm{G}$ & $\begin{array}{l}\text { Business Development Manager at South } \\
\text { West Water, Including Working on Water } \\
\text { Efficiency in Tourism Accommodation }\end{array}$ & $\mathrm{X}$ & $\mathrm{X}$ \\
\hline Participant $\mathrm{H}$ & Business Development Water Consultant & $\mathrm{X}$ & $\mathrm{X}$ \\
\hline Participant I & South West Water Environmental Projects & $\mathrm{X}$ & $\mathrm{X}$ \\
\hline Participant $\mathbf{J}$ & $\begin{array}{l}\text { University, Senior Research Fellow, } \\
\text { Researching Water Use }\end{array}$ & $\mathrm{X}$ & $\mathrm{X}$ \\
\hline Participant K & Tourism Accommodation Manager & $\mathrm{X}$ & $\mathrm{X}$ \\
\hline Participant L & Founder of a the Social Marketing Firm & $\mathrm{X}$ & $\mathrm{X}$ \\
\hline Participant M & Tourism Accommodation Manager & $\mathrm{X}$ & $\mathrm{X}$ \\
\hline Participant $\mathrm{N}$ & $\begin{array}{l}\text { University Professor of Tourism } \\
\text { Accommodation Management }\end{array}$ & $\mathrm{X}$ & $\mathrm{X}$ \\
\hline Participant $\mathrm{O}$ & Director of a Social Marketing Firm & $\mathrm{X}$ & $\mathrm{X}$ \\
\hline Participant $\mathrm{P}$ & University Lecturer in Management, Tourism & $\mathrm{X}$ & $\mathrm{X}$ \\
\hline Participant Q & University Lecturer in Management, Tourism & $\mathrm{X}$ & $\mathrm{X}$ \\
\hline Participant R & $\begin{array}{l}\text { Director of a Non-profit Water Efficiency } \\
\text { Advocacy Group }\end{array}$ & $\mathrm{X}$ & $\mathrm{X}$ \\
\hline Participant S & $\begin{array}{l}\text { Principal at Ofwat \& Director of Research } \\
\text { and Delivery at a Non-profit Water } \\
\text { Efficiency Advocacy Group }\end{array}$ & $\mathrm{X}$ & $\mathrm{X}$ \\
\hline Participant $\mathrm{T}$ & $\begin{array}{l}\text { Co-founder of a Green Tourism Certification } \\
\text { Scheme }\end{array}$ & $\mathrm{X}$ & \\
\hline Participant U & $\begin{array}{l}\text { National Parks, Manager of Sustainable } \\
\text { Tourism }\end{array}$ & $\mathrm{X}$ & \\
\hline
\end{tabular}

Source: authors

Here, an interquartile range of 1 or less, as recommended by Raskin (1994), was used for determining consensus on the impact of each initiative and factors used to rank initiatives. Interquartile range was justified for this purpose as it measures the difference between the 
values recorded at the $25^{\text {th }}$ and $75^{\text {th }}$ percentile, explaining a dispersion between data points and ensuring no large discrepancies in responses were present. To further ensure no large discrepancies existed, all data points were checked for normality as bimodal responses would represent distinct groups of disagreement, indicating a lack of consensus (Diamond et al., 2014). The metrics of percentage agreeing and disagreeing were used to determine direction of consensus. Additionally, qualitative data was collected for each section and the general nature of comments (positive, negative or mixed), determined by consensus among the research team, for each question aided in determining the direction of consensus as applied in similar work by Holey, Feeley, Dixon and Wittaker (2007). While Johnson et al. (2009) exclusively used percent agree and disagree to determine consensus in similar research, here both quantitative and qualitative data was determined to provide a more robust understanding of panel members' responses.

Since ranking initiatives was performed on a 10 point scale, due to 10 possible initiatives existing, the interquartile range was not determined to be appropriate as no precedent for such a wide scale could be found in the literature. Instead stability of weighted scores between rounds was used to determine consensus and qualitative data was collected in the form of comments to better determine direction of relationships.

\section{Results}

To determine how each initiative may affect the behaviour of key stakeholders within the tourism accommodation, five point Likert scales from strongly disagree to strongly agree measured agreement to the perceived likelihood the initiative would increase water efficiency behaviour. Participants were also provided the opportunity to make comments. Table 3 shows the results from both rounds of surveying for each initiative in descending order by 
highest mean score in round two. Note, a higher mean indicates the panel felt the initiative would have a higher impact on changing behaviour.

Table 3 Delphi panel's agreement that each initiative would change behaviour.

\begin{tabular}{|c|c|c|c|c|c|c|}
\hline Initiative & $\begin{array}{l}\text { Survey } \\
\text { Round }\end{array}$ & Mean & $\begin{array}{c}\% \\
\text { Agree }\end{array}$ & $\begin{array}{c}\% \\
\text { Disagree }\end{array}$ & $\begin{array}{c}\text { Interquartile } \\
\text { Range }\end{array}$ & $\begin{array}{c}\text { Direction } \\
\text { of } \\
\text { comments }\end{array}$ \\
\hline \multirow{2}{*}{$\begin{array}{l}\text { Remove } \\
\text { Competing } \\
\text { Behaviours }{ }^{\mathrm{d}}\end{array}$} & 1 & 4.19 & $85.7 \%$ & $4.8 \%$ & 1 & Positive \\
\hline & 2 & 4.32 & $94.7 \%$ & $5.3 \%$ & 1 & Positive \\
\hline \multirow{2}{*}{$\begin{array}{l}\text { Green } \\
\text { Ambassadors m }\end{array}$} & 1 & 4.43 & $95.2 \%$ & $0 \%$ & 1 & Positive \\
\hline & 2 & 4.21 & $89.5 \%$ & $0 \%$ & 1 & Positive \\
\hline \multirow{2}{*}{$\begin{array}{l}\text { Meaningful } \\
\text { Units of } \\
\text { Measurement }{ }^{m}\end{array}$} & 1 & 3.95 & $76.2 \%$ & $14.3 \%$ & 2 & Positive \\
\hline & 2 & 3.79 & $72.7 \%$ & $10.5 \%$ & 1 & Positive \\
\hline \multirow[t]{2}{*}{ Initial Welcome $^{\mathrm{d}}$} & 1 & 3.9 & $76.2 \%$ & $9.5 \%$ & 1 & Positive \\
\hline & 2 & 3.74 & $78.9 \%$ & $5.3 \%$ & 0 & Positive \\
\hline \multirow{2}{*}{$\begin{array}{l}\text { Low Interest } \\
\text { Loans } \mathrm{m}\end{array}$} & 1 & 3.76 & $80.9 \%$ & $14.3 \%$ & 0 & Mixed \\
\hline & 2 & 3.74 & $63.2 \%$ & $5.3 \%$ & 1 & Positive \\
\hline \multirow[t]{2}{*}{ Incentives $^{d}$} & 1 & 3.62 & $71.4 \%$ & $19 \%$ & 1 & Mixed \\
\hline & 2 & 3.58 & $63.2 \%$ & $10.5 \%$ & 1 & Positive \\
\hline \multirow{2}{*}{$\begin{array}{l}\text { Increased } \\
\text { Academic } \\
\text { Collaboration }{ }^{\mathrm{m}}\end{array}$} & 1 & 3.71 & $66.7 \%$ & $29.1 \%$ & 2 & Mixed \\
\hline & 2 & 3.42 & $47.5 \%$ & $15.8 \%$ & 1 & Negative \\
\hline \multirow{2}{*}{$\begin{array}{l}\text { Green Business } \\
\text { Scheme }{ }^{\mathrm{m}}\end{array}$} & 1 & 3.29 & $47.7 \%$ & $29.1 \%$ & 1 & Mixed \\
\hline & 2 & 3.16 & $26.3 \%$ & $21.1 \%$ & 1 & Negative \\
\hline \multirow{2}{*}{$\begin{array}{l}\text { Child Focused } \\
\text { Messages }^{\mathrm{d}}\end{array}$} & 1 & 3.19 & $38.1 \%$ & $28.6 \%$ & 2 & Mixed \\
\hline & 2 & 3.11 & $47.4 \%$ & $36.8 \%$ & 2 & Negative \\
\hline \multirow[t]{2}{*}{ Feedback Cards $^{d}$} & 1 & 2.9 & $33.3 \%$ & $28.6 \%$ & 2 & Negative \\
\hline & 2 & 2.68 & $10.5 \%$ & $42.1 \%$ & 1 & Negative \\
\hline
\end{tabular}

${ }^{\mathrm{d}}$ Indicates initiative aimed to change downstream (guest) behaviour mIndicates initiative aimed to change midstream (business) behaviour

Source: authors 
To measure consensus, again, interquartile range was used, where a 1 or less indicated consensus. The percentage agree or disagree was used to indicate direction of that consensus. In all instances, except 'child focused messages', an interquartile range of 1 or less was seen for all initiatives in round two. 'Child focused messages' had an interquartile range score of 2 and no clear direction of whether it would change behaviour (47.4\% agreed; $36.8 \%$ disagreed in round two), indicating no clear consensus was reported on this issue. However, comments revealed that this may be due to the initiative being contextual; that is, several panel members commented that 'child focused messaging' would only be appropriate in an accommodation catering to families.

With regard to all other initiatives, the direction in agreement and interquartile range suggests consensus that they would all change behaviour, excluding 'feedback cards.' 'Feedback cards' received a higher disagreement (42.1\%) than agreement (10.5\%) indicating that the panel came to consensus that it would not change behaviour to promote water efficiency. Additionally, the initiatives of 'increased academic collaboration,' 'green business schemes,' and 'child focused messages' all scored below a 50\% for agreement (though still more participants agreeing than disagreeing) that they would change behaviour. This may suggest that the panel, while in consensus that they did change behaviour, believed they would have less impact than other initiatives.

Establishing what influenced panel members to rank initiatives in a given order, ten factors were scored on a five point Likert scale from very unimportant to very important. Table 4 presents the results with factors in descending order by mean score in the second round. The higher the mean score, the higher the importance was placed upon the factor. 
Table 4 How important a given factor was used in ranking initiatives by panel members.

\begin{tabular}{|c|c|c|c|c|c|}
\hline Factor & $\begin{array}{l}\text { Survey } \\
\text { Round }\end{array}$ & $\begin{array}{c}\% \\
\text { Important }\end{array}$ & $\begin{array}{c}\% \\
\text { Unimportant }\end{array}$ & Mean & $\begin{array}{c}\text { Interquartile } \\
\text { Range }\end{array}$ \\
\hline \multirow{2}{*}{$\begin{array}{l}\text { Likelihood to change } \\
\text { guest behaviour }\end{array}$} & 1 & $95.2 \%$ & $0 \%$ & 4.43 & 1 \\
\hline & 2 & $100 \%$ & $0 \%$ & 4.68 & 1 \\
\hline \multirow{2}{*}{$\begin{array}{l}\text { Feasibility of } \\
\text { implementation }\end{array}$} & 1 & $95.2 \%$ & $4.8 \%$ & 3.95 & 2 \\
\hline & 2 & $100 \%$ & $0 \%$ & 4.63 & 1 \\
\hline \multirow{2}{*}{$\begin{array}{l}\text { Likelihood to have } \\
\text { minimal negative } \\
\text { effects on the guest } \\
\text { experience }\end{array}$} & 1 & $81 \%$ & $4.8 \%$ & 4.33 & 1 \\
\hline & 2 & $89.5 \%$ & $0 \%$ & 4.37 & 1 \\
\hline \multirow[t]{2}{*}{ Financial costs } & 1 & $95.3 \%$ & $0 \%$ & 4.24 & 1 \\
\hline & 2 & $94.7 \%$ & $0 \%$ & 4.32 & 1 \\
\hline \multirow{2}{*}{$\begin{array}{l}\text { Desire of tourism } \\
\text { accommodation } \\
\text { businesses to } \\
\text { implement }\end{array}$} & 1 & $95.2 \%$ & $4.8 \%$ & 4.24 & 1 \\
\hline & 2 & $94.7 \%$ & $0 \%$ & 4.26 & 1 \\
\hline \multirow{2}{*}{$\begin{array}{l}\text { Likelihood to change } \\
\text { businesses' } \\
\text { management of water }\end{array}$} & 1 & $90.5 \%$ & $0 \%$ & 4.29 & 1 \\
\hline & 2 & $84.2 \%$ & $0 \%$ & 4.05 & 0 \\
\hline \multirow{2}{*}{$\begin{array}{l}\text { Previously established } \\
\text { evidence supporting } \\
\text { positive outcomes }\end{array}$} & 1 & $81 \%$ & $0 \%$ & 4.24 & 1 \\
\hline & 2 & $73.7 \%$ & $5.3 \%$ & 3.89 & 1 \\
\hline \multirow{2}{*}{$\begin{array}{l}\text { Overall amount of } \\
\text { water likely to be save } \\
\text { through the initiative }\end{array}$} & 1 & $85.7 \%$ & $9.5 \%$ & 4 & 1 \\
\hline & 2 & $73.7 \%$ & $0 \%$ & 3.89 & 1 \\
\hline \multirow{2}{*}{$\begin{array}{l}\text { Contains measureable } \\
\text { outcomes for } \\
\text { evaluation purposes }\end{array}$} & 1 & $81.1 \%$ & $14.3 \%$ & 3.76 & 0 \\
\hline & 2 & $63.1 \%$ & $0 \%$ & 3.74 & 1 \\
\hline \multirow{2}{*}{$\begin{array}{l}\text { High level of support } \\
\text { from other } \\
\text { stakeholders (e.g. } \\
\text { Government, non- } \\
\text { profits, water } \\
\text { companies, media, } \\
\text { etc.) }\end{array}$} & 1 & $42.8 \%$ & $14.3 \%$ & 3.42 & 1 \\
\hline & 2 & $47.4 \%$ & $21.1 \%$ & 3.32 & 1 \\
\hline
\end{tabular}

Source: authors

Again, an interquartile range of 1 or less was used to establish consensus. To understand direction, the percentage of individuals reporting it was unimportant versus important was used. For every factor, consensus was reached in round two. While every 
factor was reported to be important, and the comments also supported this observation, some were reported to be more important than others.

Results show the panel placed the highest importance on focusing on changing guest behaviour (downstream), indicated by the highest mean score for 'likelihood to change guest behaviour' (4.68). This was followed by practical concerns such as feasibility (4.63), financial costs (4.32), likelihood to have a negative effect on the guest experience (4.37) and desire for businesses to implement the initiative (4.26). The panel then prioritized changing business (mid-stream) practices (4.05). Following more theoretical issues were prioritized such as established evidence that the initiative would be successful (3.89), overall water saved (3.89) and ability to measure project success (3.74). Finally, the factor of having high stakeholder support (3.32) which could be considered an effort to incorporate upstream partners, received the lowest score.

Importantly, the panel was also asked to rank initiatives based on priority for implementation. Table 5 presents the findings from both rounds with initiatives in descending order from most to least prioritized using a weighted score. Initiatives did not change in ranking from round to round indicating consensus on the issue. While interquartile range was not used due to a lack of support in the literature for this method, the values decreased in every instance from round 1 to round 2, also indicating a shift toward consensus. The initiative 'removal of competing barriers' was ranked highest while 'increased academic collaboration' was ranked lowest. 
Table 5 Delphi panel's prioritization of initiatives to be enacted.

\begin{tabular}{|c|c|c|c|c|}
\hline Initiative & $\begin{array}{l}\text { Survey } \\
\text { Round }\end{array}$ & $\begin{array}{c}\text { Interquartile } \\
\text { Range }\end{array}$ & $\begin{array}{c}\text { Weighted } \\
\text { Score } \\
\end{array}$ & $\begin{array}{c}\text { Overall } \\
\text { Ranking }\end{array}$ \\
\hline \multirow[t]{2}{*}{ Remove Competing Behaviours $^{\mathrm{d}}$} & 1 & 5 & 159 & 1 \\
\hline & 2 & 0 & 186 & 1 \\
\hline \multirow[t]{2}{*}{ Initial Welcome $^{\mathrm{d}}$} & 1 & 4 & 147 & 2 \\
\hline & 2 & 2 & 149 & 2 \\
\hline \multirow{2}{*}{ Incentives $^{d}$} & 1 & 5 & 139 & 3 \\
\hline & 2 & 1 & 147 & 3 \\
\hline \multirow[t]{2}{*}{ Green Ambassadors ${ }^{m}$} & 1 & 5 & 137 & 4 \\
\hline & 2 & 2 & 126 & 4 \\
\hline \multirow{2}{*}{$\begin{array}{l}\text { Meaningful Units of } \\
\text { Measurement } \mathrm{m}\end{array}$} & 1 & 4 & 119 & 5 \\
\hline & 2 & 3 & 107 & 5 \\
\hline \multirow{2}{*}{ Feedback Cards $^{\mathrm{d}}$} & 1 & 5 & 109 & 6 \\
\hline & 2 & 1 & 85 & 6 \\
\hline \multirow[t]{2}{*}{ Low Interest Loans $\mathrm{m}$} & 1 & 7 & 98 & 7 \\
\hline & 2 & 3 & 80 & 7 \\
\hline \multirow[t]{2}{*}{ Green Business Scheme ${ }^{m}$} & 1 & 3 & 91 & 8 \\
\hline & 2 & 2 & 61 & 8 \\
\hline \multirow{2}{*}{ Child Focused Messages ${ }^{\mathrm{d}}$} & 1 & 3 & 89 & 9 \\
\hline & 2 & 3 & 58 & 9 \\
\hline \multirow{2}{*}{$\begin{array}{l}\text { Increased Academic } \\
\text { Collaboration }{ }^{\mathrm{m}}\end{array}$} & 1 & 4 & 77 & 10 \\
\hline & 2 & 2 & 46 & 10 \\
\hline
\end{tabular}

${ }^{\mathrm{d}}$ Indicates initiative aimed to change downstream (guest) behaviour mIndicates initiative aimed to change midstream (business) behaviour

Source: authors

\section{Discussion}

Four initiatives were highly prioritized by the panel: 'remove barriers to change,' 'initial welcome,' 'incentives' and 'green ambassadors.' However, of these four initiatives, 'incentives' scored the lowest for agreement (only 63.2\%) that it would change behaviour. Additionally, Borden, Coles and Shaw (2017) report that incentives are not always a possibility for smaller tourism accommodation firms and may therefore not be a viable option for intervention. Interestingly, 'feedback cards' were highly supported by guests in earlier research stages as reported by Borden, Coles and Shaw (2017). However, the Delphi panel felt they were likely to be completed after the guest experience and therefore have little effect on their behaviour while staying in the accommodation. It is therefore recommended that the 
three initiatives of 'removing barriers to change,' 'initial welcome' and 'green ambassadors' be pursued to reduce water usage in the South West English tourism accommodation industry. Incentives, if financially viable for tourism firms, may also be effective.

Results also have implications for contemporary theory in the field of social marketing. First, downstream targeting (changing guest behaviour) was the highest rated factor for prioritizing initiatives. This was also supported by the top three prioritized initiatives being downstream efforts, despite some midstream initiatives ranking in the top three for impact on behaviour. While these results represent only one example, they support observations by Andreasen (2006) that downstream marketing receives the highest degree of attention in practical application despite calls for more upstream focus (French et al., 2010; Hall, 2013). Calls for more upstream targeting are commonly supported by the claim that they could have larger impacts on behaviour (Hall, 2016). The surprisingly low score for 'overall amount of water saved' in this research accentuates the potential disconnect shown by this panel. It therefore appears the Delphi panel was more concerned with changing downstream behaviour than saving water. While an explanation for why downstream targeting is so prevalent is beyond the scope of this paper, it would seem a clear area for future research. Findings also prove pragmatic for the recent urgent appeals to 'follow and report established theory' (Shepard et al., 2009; Luca and Suggs, 2013) and 'evaluate campaign success' (Hall, 2014; French et al., 2010) where similar factors scored below a desire for downstream targeting and practical concerns (i.e. financial costs and feasibility). Together results may suggest that in practice, social marketing campaigns operate differently than theoretical best practices. That of course does not mean that theoretical best practices should be overlooked, rather it identifies barriers to progressing the field. It is hoped that understanding such barriers could aid future researchers and practitioners in developing more effective social marketing initiatives. 
Returning to the points from Stitt-Gohdes and Crews (2004) reviewed previously, within the context of this research, the Delphi method arguably can be seen as a valuable tool in helping to achieve research objectives. That is, the Delphi method displayed advantages over other potential efforts to evaluate outcomes. For example, the Delphi method represented a lower cost alternative that avoided several practical barriers which existed for other evaluation tools. This survey was conducted remotely over three weeks and did not incur any costs. In contrast, the project briefly considered co-creation as a final stage to evaluate and prioritize initiatives with both tourism accommodation guests and managers being together in the same geographical location. However, assembling these two groups together proved logistically and financially restrictive as tourist did not want to spend their vacation in meetings and managers requested to be compensated for missing key work hours. Finally, the autonomy of the evaluating panel may have contributed to a clearer and less biased outcome. For example, Gupta and Clarke (1996) argue that the autonomy offered by of the Delphi method may avoid the 'halo effect,' where members are influenced by other participants with 'higher status.' Also, as previously explored in the literature review of this paper, social marketing can work with behaviours that are emotionally difficult and again autonomy may be an asset to circumvent peer pressure. In this research, the benefits of autonomy were not clearly stated by panel members nor overly apparent. This could be due to the relatively safe topic, prompting water efficiency, of the campaign. However, the benefits of autonomy may have been realized through more subtle means and would surely be important in social marketing campaigns addressing difficult topics (i.e. drug addiction; rape prevention; domestic violence).

From these examples, the application of the Delphi method would appear to be deserving of more attention. However, within the social marketing context, several limitations examined in the literature review of this paper need further attention to ensure it is 
utilized correctly in the future. Specifically, as several authors have identified (e.g. Gibbs, Graves and Bernas, 2001; Garrod and Fyall, 2005; Diamond et al., 2014), the selection of appropriate panel members is vital to the quality and integrity of results. First, it is recommended that a heterogeneous sample is used in social marketing research due to its previous support in the literature, the multidisciplinary nature of social marketing and the benefits to the research findings reported within this project. Additionally, as previously identified, some of the Delphi participants were previously known to the researchers (under 20\%). When applying a Delphi consultation to build consensus among stakeholders, this may be unavoidable. At the end of a social marketing campaign it is the people with the greatest familiarity with the issues and process that need to be most involved in deciding the outcomes. However, if participants are previously known to researchers, a clear possibility for bias exists where, whether intentional or not, researchers could choose individuals with similar opinions to themselves or influence participants through the 'halo effect.' While in this research we were able to involve a relatively low number of past colleagues, we would recommend selection of under 50\% previously known participants to ensure a balance between these two competing issues.

Next, while no consensus on sample size exists, it is recommended to have a higher sample size for heterogeneous groups compared to homogeneous groups (Kerr and Patti, 2013). Larreche and Montgomery (1977) and Taylor and Judd (1994) recommend a final sample size of 15-30 individuals for heterogeneous groups. Due to the difficulty of many social marketing topics, confidentiality of data and recipients is recommended at all times. Finally, as proposed by Diamond et al., (2014), rationalization for panel members should be determined based on a set of predetermined criteria prior to their selection. Reporting of these criteria and other vital information, identified by Diamond et al. (2014), of the Delphi process (e.g. how the researchers will determine consensus; the dropping of any items 
between rounds; what was shared with participants between rounds; which stopping rules were used, etc.) will ensure the maximum value is realized from the Delphi method in future social marketing campaigns.

In conclusion, this research represents one example of a Delphi consultation, specific to tourism and water behaviour in South West England, and therefore may not be applicable to other behaviours or locations. However, three initiatives have been identified and recommended for implementation to reduce water usage in the tourism industry in South West England. Since the conclusion of this research, all participating businesses from each of the three stages have been consulted with on the subject and several efforts have been made (i.e. subtractions of baths and additions of introductory welcomes) to reduce water usage.

The Delphi method has been presented as a potential tool towards building consensus on the impact and prioritization of multiple campaign initiatives. Within this research effort, while best practices need to be adhered to within the context of social marketing to ensure maximum value is realized, the Delphi method proved to be a valuable tool in helping to achieve the research objectives. Further research, applying the Delphi method within the social marketing context, would aid in affirming and refining recommendations for its application. Such research could address the multiple discrepancies between 'real life' application and theoretical best practices, identified in this research, to further progress the field of social marketing. 


\section{References}

Adler, M. and Ziglio, E. (1996), Gazing into the Oracle: The Delphi Method and its Application to Social Policy and Public Health, Kingsley Publishers, London, England.

Andreasen, A.R. (2006), Social Marketing in the $21^{\text {st }}$ Century, Sage Publications, Thousand Oaks, CA.

Andreasen, A.R. (2012), "Rethinking the relationship between social/non-profit marketing and commercial marketing", Journal of Public Policy and Marketing, Vol. 31 No. 1, pp. 36-41.

Aschemann-Witzel, J., Perez-Cueto, F.J., Niedzwiedzka, B., Verbeke, W. and Bech-Larsen, T. (2012), "Transferability of private food marketing success factors to public food and health policy: An expert Delphi survey", Food Policy, Vol. 37 No. 6, pp. 650660.

Best, R.J. (1974), An experiment in Delphi estimation in marketing decision making. American Marketing Association, Vol. 11 No.4, pp. 448-452.

Bloom, P. N. and Novelli W. D. (1981), "Problems and challenges in social marketing", Journal of Marketing, Vol. 45, pp. 79-88.

Borden, D.S., Coles, T. and Shaw, G. (2016) Social marketing, sustainable tourism and SMTEs: Challenges and opportunities for changing guest behavior. Journal of Sustainable Tourism. DOI: 10.1080/09669582.2016.1270952

Bowers, J. (1997), Sustainability and Environmental Economics: an Alternative Text, Longman, Harlow, UK.

Buckley, C. (1995), "Delphi: a methodology for preferences more than predictions. Library Management", Library Management, Vol. 16 No. 7, pp. 16-19.

Coles, T., Warren, N., Borden, D.S. and Dinan, C (2016) Business models among SMTEs: Locating environmental costs. Journal of Sustainable Tourism. DOI: 10.1080/09669582.2016.1221414

Diamond, I. R., Grant, R.C., Feldman, B.M., Pencharz, P.B., Ling, S.C, Moore, A.M. and Wales, P.W. (2014), "Defining consensus: A systematic review recommends methodological criteria for reporting Delphi studies", Journal of Clinical Epidemiology, Vol. 67, pp. 401-409.

Domegan, C., Collins, K., Stead, M., McHugh, P., Hughes, T. (2013) "Value co-creation in social marketing: functional or fanciful?", Journal of Social Marketing, Vol. 3 No. 3, pp. 239-256.

Fox, K.F.A., and Kotler, P. (1980), "The marketing of social causes: the first 10 years", The Journal of Marketing, Vol. 44 No. 4, pp. 24-33.

French, J., Blair-Stevens, C., McVey, D. and Merritt, R. (2010), Social Marketing and Public Health, Theory and Practice, Oxford University Press, Oxford, England.

Garrod, B. and Fyall, A. (2005), "Revisiting Delphi: the Delphi technique in tourism research", In, Ritchie, B.W., Burns, P. and Palmer, C. (Eds.) Tourism Research Methods: Integrating Theory with Practice, CABI Publishing, Oxfordshire, UK, pp. 85-98.

Gibbs, W., Graves, P. R. and Bernas, R. S. (2001), "Evaluation guidelines for multimedia courseware", Journal of Research on Technology in Education, Vol. 34 No. 1, pp. 217.

Griffiths, J., Blair-Stevens, C. and Parish, R. (2009), "The integration of health promotion and social marketing", Perspectives in Public Health, Vol. 129 No. 6, pp. 268-271. 
Gupta, U., and R. Clarke. (1996), "Theory and Applications of the Delphi Technique: A Bibliography (1975-1994)", Technological Forecasting and Social Change, Vol. 53, pp. 185-211.

Hall, M.C. (2013), "Framing behavioural approaches to understanding and governing sustainable tourism consumption: Beyond neoliberalism, 'nudging' and 'green growth'?", Journal of Sustainable Tourism, Vol. 21 No. 7, pp. 1091-1109.

Hall, M.C. (2014), Tourism and Social Marketing, Routledge, London, England.

Hall, M.C. (2016), "Intervening in academic interventions: framing social marketing's potential for successful sustainable behaviour change", Journal of Sustainable Tourism, Vol. 24 No. 3, pp. 350-375.

Hastings, C. (2007), Social Marketing: Why Should the Devil have all the Best Tunes?, Elsevier, Oxford, England.

Holey, E.A., Feeley, J.L., Dixon, J. and Wittaker, V.J. (2007), "An exploration of the use of simple statistics to measure consensus and stability in Delphi studies", BMC Medical Research Methodology, Vol. 7 No. 52, doi 10.1186/1471-2288-7-52.

Hsu, C.C. and Sandford, B.A. (2007), "The Delphi technique: making sense of consensus", Practice Assessment, Research and Evaluation, Vol. 12, pp. 1-7.

Johnson, K. M., Jones, S. C., and Iverson, D. (2009), "Guidelines for the development of social marketing programmes for sun protection among adolescents and young adults", Public health, Vol. 123, e6-10.

Jones, S.C., Johnson, K, Talenta, J., Thom, J.A., Williams, M., Iverson, D. and Caputi, P, (2014), "Don't let the sun get under your skin: Targeting adolescent sun protection with a novel social marketing campaign", In Hastings, G. and Domegan, C., Social Marketing: From Tunes to Symphonies, Second edition, Routledge, New York, NY.

Kerr, G. and Patti, C. (2015), "Strategic IMC: From abstract concept to marketing management tool", Journal of Marketing Communication Vol. 21 No. 5, pp. 317-339.

Larreche, J., and D. Montgomery. (1977), "A Framework for the Comparison of Marketing Models: A Delphi Study”, Journal of Marketing Research, Vol. 14 No. 6, pp. 487498.

Lee, N.R. and Kotler, P. (2011), Social Marketing: Influencing Behaviour for Good, SAGE Publications, Inc., London, England.

Lee, N.R. and Kotler, P. (2015), Social Marketing: Changing Behaviours for Good, $5^{\text {th }}$ Edition, SAGE Publications, Inc., London, England.

Ling, J.C., Franklin, B.A., Lindsteadt, J.F. and Gearon, S.A. (1992), "Social marketing: its place in public health", Annual review of public health, Vol. 13 No. 1, pp.341-362.

Linstone, H., and Turoff, M. (1975), The Delphi Method: Techniques and Applications, Addison-Wesley, Reading, MA.

Luca, N.R. and Suggs, L.S. (2013), "Theory and model use in social marketing health interventions", Journal of Health Communications, Vol. 18 No. 1, pp. 20-40.

McKenzie-Mohr, D. and Smith, W. (1999), Fostering Sustainable Behaviour: An introduction to Community-Based Social Marketing, New Society Publishers, Gaboriola Island.

Niblett, G.R. (2005), "Stretching the limits of social marketing partnerships, upstream and downstream: Setting the context for the 10th innovations in social marketing conference", Social Marketing Quarterly, Vol. 11 No. 3-4, pp. 9-15.

Okoli, C., and Pawlowski, S. (2004), "The Delphi method as a research tool: An example, design considerations and applications”, Information \& Management, Vol. 42, pp. $15-29$.

Powe, C. (2003), "The Delphi technique: myths and realities", Journal of Advanced Nursing, Vol. 41 No. 4, pp. 376-382. 
Raskin, M.S. (1994), "The Delphi study in field instruction revisited: expert consensus on issues and research priorities", Journal of Social Work Education, Vol. 30 No. 1, pp. 75-89.

Richards, J., and C. Curran. (2002), “Oracles on Advertising: Searching for a Definition”, Journal of Advertising, Vol. 31 No. 2, pp. 63-77.

Rowe, G. and Wright, G. (1999), "The Delphi technique as a forecasting tool: issues and analysis". International Journal of Forecasting, Vol. 15, pp.353-375.

Russell-Bennett, R., Wood, M. and Previte, J. (2013), "Fresh ideas: services thinking for social marketing”, Journal of Social Marketing, Vol. 3 No. 3, pp. 223-238.

Shaw, G., Barr, S. and Wooler, J. (2013), "The application of social marketing to tourism", In McCabe, S. (Ed.), The Routledge Handbook of Tourism Marketing, Taylor and Francis Ltd, London, England, pp. 54-64.

Shepard, S. Lewin, S. Straus, S., Clarke, M., Eccles, M.P., Fitzpatrick, R., Wong, G. and Sheikh, A. (2009), "Can we systematically review studies that evaluate complex interventions?", PLoS Med, Vol. 6 No. 8, e1000086. doi:10.1371/journal.pmed.1000086

Smith, S.L.J. (1995), Tourism Analysis: A Handbook, $2^{\text {nd }}$ edition. Longman, Harlow, UK.

South West Water (2016) Love your loo. Available at: http://www.southwestwater.co.uk/loveyourloo [Accessed: July 9, 2016].

Stewart, T.R. (1987), "The Delphi technique and judgemental forecasting", Climate Change, Vol. 11, pp. 97-113.

Stitt-Gohdes, W.L. and Crews, T.B. (2004), "The Delphi technique: a research strategy for career and technical education", Journal of Career and Technical Education, Vol. 20 No. 2, ISSN: 1531-4952.

Tafreshi, P., Aghdaie, M., Behzadian, M., Mahdieh, A. (2015), "Developing a group decision support system for advertising media evaluation: A case study of the Middle East", Group Decision and Negotiation, Springer online publication, pp.1-28, doi: 10.1007/s10726-015-9464-4.

Taylor, R., and Judd. L. (1994), "Delphi forecasting”, In Witt, S. and Moutinho, L.(Eds.), Tourism Marketing and Management Handbook, Prentice Hall, London, England, pp. 535-539.

Young, Y.W., Keng, K.A. and Leng, T.L (1989), “A Delphi forecast for the Singapore tourism industry: future scenario and marketing implications", International Marketing Review, Vol. 6, pp. 35-46. 